\section{Unprecedented Move}

\section{Dr. Venkat Pulla ${ }^{\dagger}$}

In parallel with the historic elections of the United States of America on 8 November 2016, with Donald Trump becoming the 45th President Elect, the Government of India (GOI) took the nation by an utter disbelief by compelling a ground-breaking step to demonetise ?500 and ?1000 denominations from the length and breadth of India and its financial system to deal with at least one pathological condition that plagues the country: the pervasive corruption in India. The measures of Modi Government are expected to repress black money; curb circulation of fake notes; check on terror-financing from across the borders; restrict if not completely banish corrupt practices and finally bring in modest controls on inflation. India under Modi has ushered in an interesting mix of crucial economic initiatives such as the launch of Make in India in September 2014 and the implementation of Pradhan Mantri Jan-Dhan Yojana and now the scrapping of 9500 and ?1000. Although this was not one of Modi's pre-poll promises but bringing back the black money deposited in the Swiss Banks was. Amongst what are known as white papers on Black Money released by the Ministry of Finance, GOI, 2012, a total of CHF 1.95 billion (国2.95 billion, US\$2.1 billion) remained deposited in all the Swiss Banks, but the domestic and diplomatic measures taken by the Modi Government has plummeted the level of black money to approximately CHF 1.2 billion or 国 83.92 billion in $2016 .^{1}$

\footnotetext{
${ }^{\dagger}$ Coordinator, Social Work Discipline \& Senior Lecturer, Australian Catholic University, Australia (Brisbane Campus), Emails: Venkat.pulla@acu.edu.au; dr.venkat.pulla@gmail.com

${ }^{1}$ Money owned by Indians in Swiss banks drops to record low of Rs 8,392 crore. The Indian Express. Retrieved from, http://indianexpress.com/article/business/economy/mo ney-owned-by-indians-in-swiss-banks-drops-to-recordlow-of-rs-8392-crore/
}

(C) 2016 Pulla, Venkat. This is an Open Access article distributed under the terms of the Creative Commons Attribution License (http://creativecommons.org/licenses/by/2.0), which permits unrestricted use, distribution, and reproduction in any medium, provided the original work is properly cited.

\section{The Current Issue}

The current issue has articles by a number of Bhattacharya, Suman Singh, Pranalee Sharma and Asha Singh, Dhurjjati Sarma, Syeda Sakira Sahin, Sushmita Chakraborty and Namita Chakma, and Mr. Mahadeb Ghosh and Biswaranjan Mistri. I am personally grateful for their contributions.

In the 2016 Monsoon session of the Parliament, the GOI took an unparalleled move to pass the most contentious The Constitution (122nd Amendment) (GST) Bill, 2014 on 8 August 2016. The notion of 'development' (vikas) of Mr. Modi is undoubtedly a mega concept but I am yet to be convinced that there are adequate measures undertaken to safeguard the poor while driving the humongous journey of vikasthat the poor (who are already stuck in poverty) are not hit hard and pushed further into the bane of poverty. The GST article by Dr. Ratul Mahanta in the current issue of our journal (Volume 4, No. 2) makes a candid explanation of how it works.

Commercial surrogacy is blasphemous on a number of counts. Renting third-world wombs most often due to poverty and (or) other reasons has to be abhorred. Dr. Rituparna Bhattacharyya addresses this problem in a timely topical article in this issue once again highlighting the attitudes towards the thirdworld mothers who rent their wombs. The powerful narratives within speak clearly of how medical tourism has contributed additionally to this denigrating trade that sans medical ethics and all reasonable care for the surrogate in case of the death of the child or worse still in the death of the surrogate-a body turned into a corpse while the live merchandise is quietly shipped away.

The Maternity Benefit (Amendment) Bill, 2016 was introduced and passed in the Rajya Sabha on 11 August 2016 but yet to be passed in the Lok Sabha. Dr. Suman Singh offers a critical authors: Rahul Mahanta, Rituparna 
review of this bill to make the readers (especially the new mothers) better understand the issues linked to maternity and how the GOI aims to protect its women employees during their maternity period.

In the Special Article section we publish three articles - the first two relates to the Vaishnava Saint, Mahapurush Srimanta Sankardeva (1449-1568) who initiated the Bhakti movement (Neo-Vaishnavite Movement) in the form of Ekasarana Dharma embedded in egalitarian principles. Mahapurush Srimanta Sankardeva, a multi-talented saint-a scholar, poet, playwright, social-religious reformer chose Majuli-a riverine island-geo-spatially located in the north of Jorhat town, Assam to establish and preach the pristine cultural heritage of the state and established the Vaisnavite shrines, popularly known as the Satras. Indeed, these Satras have emerged as the spaces of principal pilgrimage for over the last 400 years. The joint article by Miss Pranalee Sharma and Dr. Asha Singh sketches as to how the notion of ideal monkhood has gradually been changing in the face of increasing materialism due to impact of globalisation. Using the readings of Syed Abdul Malik's Dhanya Nara Tanu Bhal and Rudrani Sarma's Lauhitya Tirar Amrit Gatha as lenses, Mr. Dhurjjati Sarma makes an attempt to illustrate Vaishnavite Hagiography. In a totally different context, using feminist approaches, Dr. Syeda Sakira Sahin tried to paint how women within localities develop communities of their won and how they operate.

The first article in the research section is on rural development of Sikkim, where Miss Sushmita Chakraborty and Dr. Namita Chakma have discussed how the Sikkim Government has not only taken assertive steps to develop ecotourism via the mode of homestay business but have also developed organic farming to scaleup the growth of rural economy of Sikkim. Mr. Mahadeb Ghosh and Dr. Biswaranjan Mistri discuss the literacy rates and its impact on the rates of birth in the Nadia District of West Bengal. Finally, as usual we have compiled for you the PUBLICATION WATCH.
Before, I conclude, it is worth mentioning that our journal is steadily growing, clearly owing to the dedication of Rituparna Bhattacharya and able supported by Dhurjjati Sarma, Shabeena Ahmed and the technical team. I am sure many other editorial board members have contributed to the past issues and have promised to contribute to the forthcoming issues; clearly this is positively affecting the Index Copernicus, popularly known as ICV. The value for Space and Culture India has been evaluated for 2015 as 78.51. It was 4.60 in 2012 which increased to 5.11 in 2013 through to 54.50 in $2014 .^{2}$

I take this opportunity to thank all authors, readers and reviewers for continued support.

\section{References}

Black Money (2012). White Paper, Ministry of Finance, Department of Revenue, Central Board of Direct Taxes, New Delhi, Retrieved from, http://finmin.nic.in/reports/WhitePaper_Back Money2012.pdf

Kaushal, Pradeep (2016, 13 August). Parliament's Monsoon session, summarised. The Indian Express. Retrieved from, http://indianexpress.com/article/opinion/webedits/parliaments-monsoon-sessionsummarised-lok-sabha-rajya-sabha-2972365/

\footnotetext{
${ }^{2}$ http://jml2012.indexcopernicus.com/Space+and+Cultur e+India,p4739,3.html
} 